\title{
THE RUSSIAN POPULATION OF THE NEAR ABROAD: GEODEMOGRAPHIC DYNAMICS \\ OF THE POST-SOVIET PERIOD
}

\section{SERGEY SUSHCHIY}

\begin{abstract}
This article explores the geodemographic dynamics of the Russian population of the near abroad in the postSoviet period. It analyzes the quantitative changes and transformation of its geography, the level of urbanization and the gender and age structure. The study shows that in the post-Soviet period there was a sharp decline in the number of Russians in all of the near abroad. This process was most intensive in the 1990s. The maximum demographic losses during this period were suffered by the Russian population of Transcaucasia and a number of countries in Central Asia. At the beginning of the twenty-first century, the rate and absolute scale of decline are decreasing, but the trend itself remains stable. This is associated with the natural decline of the Russian population, its migration to Russia and foreign countries, and assimilation. The relationship of these factors to the quantitative decline has varied across time and across individual countries. In almost all Russian communities a significant preponderance of women is recorded. The median age of Russians in all countries of the near abroad is more than 40 years. The level of urbanization of Russians in most of these countries has decreased. Better preserved are the metropolitan and rural Russian populations. The demographic ratio of the Russian communities of individual countries and macroregions has changed. The numbers of Russians in Kazakhstan and Ukraine (without the people's republics of Donbass) are already comparable, and there are more Russians in the Baltic countries than in Central Asia. Russian communities of unrecognized (or partially recognized) States are characterized by increased demographic stability.
\end{abstract}

Key words: the near abroad, Russian population, geodemographic dynamics, sex and age structure, level of urbanization, migration, assimilation.

\section{INTRODUCTION AND PROBLEM STATEMENT}

According to the last Soviet census (December 1989), the number of Russians in the Union Republics of the USSR was 25.3 million (All-Union census ... 1989). Thus, the breakup of the Soviet Union into 15 States and the emergence of the near abroad led to one of the biggest transformations in the State-political system of the settlement of the Russian people in its history. Almost $20 \%$ of the total number of Russians ended up outside their country ${ }^{1}$.

SERGEy SuSHChIY (SS7707@mail.ru), SOUTHERN SCIENTIFIC CENTER OF THE RuSSIAN ACADEMy OF SCIENCES, RUSSIA.

THE PUbliCATION WAS PREPARED AS PART OF THE IMPLEMENTATION OF THE STATE TASK OF THE SOUTHERn SCIENTIFIC CENTER OF THE RUSSIAN ACADEMY OF SCIENCES, PROJECT NO. AAAA19-119011190184-2.

THE ORIGINAL ARTICLE IN RUSSIAN WAS PUBLISHED IN DEMOGRAPHIC REVIEW IN 2019, 7(2), 6-30. DOI: DOI.ORG/10.17323/DEMREVIEW.V7I2.11137

\footnotetext{
${ }^{1}$ For the overwhelming majority of the Russian population of not only the union republics, but also of the RSFSR, the USSR was "their" country.
} 
From the moment the near abroad appeared, its Russian population began to noticeably influence the quantitative dynamics of the entire Russian people. Russian communities also played a significant role in the ethno-demographic processes of the new post-Soviet States. In Kazakhstan, Latvia and Estonia in the early 1990s, Russians accounted for 37, 33 and 30\% of the population, respectively, and in two other countries (Ukraine and Kirgizia) they accounted for more than 1/5 of the population. In all these countries, Russians were essentially the second most numerous people.

In the near abroad one can distinguish several macroregions whose historical, sociocultural and socio-economic specifics determined many significant geodemographic indicators of the local Russian population (including its total number, geographical distribution and forms of settlement, and level of interethnic marriage). The northwestern macroregion includes the Baltic states, the western region includes Ukraine, Belarus and Moldova. The third region is made up of the states of Transcaucasia, the fourth of Central Asia (Kazakhstan and the countries of Central Asia). But it should be noted that the most general trends in the geodemographic dynamics of the Russian population in the post-Soviet period coincided for all macro-regions of the post-Soviet space.

\section{RESEARCH OVERVIEW AND INFORMATION BASE}

The demographic dynamics of the Russian population of the near abroad, its migration activity and involvement in assimilation processes, have attracted the attention of many researchers (Kabuzan 1996; Rybakovsky 1996; Savoskul 2001). Many works are devoted to the Russians of individual countries and macroregions of Ukraine and Moldova (Mitrofanova, Sushi 2017; Ostapenko, Subbotina 2011; Romantsov 2008), the Baltic states (Volkov 2013; Manakov, Chuchenkova 2016; Manakov 2020; Martsinkevichus 2013; Nikifirov, Poleshchuk 2013; Suschiy 2018a; Hallik 2011), Transcaucasia (Mosaki 2018; Tsutsiev 2006; Yunusov²), Kazakhstan and Central Asia (Aleinikov, Borovikov 2013; Suschiy 2018b; Tishkov 1993; Fedorko, Kurbanov 2018; Khoperskaya 2012).

However, in most of these works the specifically geodemographic aspects of the life of Russian communities in the post-Soviet space are on the periphery of research interest. Even more important is the fact that there is a noticeable shortage of general works devoted to the quantitative, spatial, and settlement dynamics of the Russian population of the entire near abroad, to shifts in the ratio of its leading communities.

The information sources of the study are materials of the USSR 1989 population census (All-Union census ... 1989) and results of post-Soviet censuses posted on the websites of state statistical committees of countries of the near abroad. Some of these statistical materials are collected on the website "Population statistics of Eastern Europe and the former USSR" 3 .

\footnotetext{
${ }^{2}$ Yunusov A.S. (2003). Ethnic and migration processes in post-Soviet Azerbaijan. URL: http://chairs.stavsu.ru/geo/Conference/c1-67.htm

${ }^{3}$ URL: http://pop-stat.mashke.org 
It should be borne in mind that the countries of the post-Soviet space differ in both the number and timing of censuses (Table 1). Expert fine-tuning of this statistical information is required to bring it into the general picture of the geodemographic dynamics of the Russian population within the former USSR. This analysis is complicated by the fact that Ukraine, which at the turn of the 1990s accounted for $46 \%$ of Russians in the near abroad, has not conducted a census since 2001, the results of which are now significantly outdated. And Uzbekistan, with the largest Russian community in Central Asia, in the post-Soviet period has done without censuses altogether ${ }^{4}$. Ethno-demographic statistics for Turkmenistan are also extremely limited (the results of the 1995 census are significantly inflated (Zhukov, Reznikova 2001: 31-47), and the 2012 census has not been published).

Table 1. Population censuses in countries of the near abroad, 1990-2010s

\begin{tabular}{|c|c|c|c|c|c|c|c|c|c|c|c|c|c|}
\hline Territory & ฉ̊ & 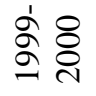 & 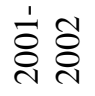 & 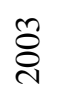 & $\underset{ঠ}{ষ ্ ণ ~}$ & §̊ & 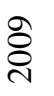 & $\stackrel{\circ}{\circ}$ & ন্ণ & $\frac{N}{\delta}$ & 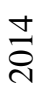 & $\frac{n}{8}$ & $\frac{a}{\circ}$ \\
\hline Azerbaijan & & $*$ & & & & & $*$ & & & & & & $*$ \\
\hline Belarus & & $*$ & & & & & $*$ & & & & & & $*$ \\
\hline Georgia & & & $*$ & & & & & & & & $*$ & & \\
\hline Ukraine & & & $*$ & & & & & & & & & & \\
\hline \multicolumn{14}{|l|}{ Uzbekistan } \\
\hline Tajikistan & & $*$ & & & & & & $*$ & & & & & \\
\hline Turkmenistan & $*$ & & & & & & & & & $*$ & & & \\
\hline Kazakhstan & & $*$ & & & & & $*$ & & & & & & \\
\hline Kirgizia & & $*$ & & & & & $*$ & & & & & & \\
\hline Armenia & & & $*$ & & & & & & $*$ & & & & \\
\hline Lithuania & & & $*$ & & & & & & $*$ & & & & \\
\hline Latvia & & $*$ & & & & & & & $*$ & & & & \\
\hline Estonia & & $*$ & & & & & & & $*$ & & & & \\
\hline Moldova & & & & & $*$ & & & & & & $*$ & & \\
\hline \multicolumn{14}{|c|}{ Unrecognized and partially recognized States of the near abroad } \\
\hline Abkhazia & & & & $*$ & & & & & * & & & & \\
\hline Nagorno-Karabakh & & & & & & $*$ & & & & & & $*$ & \\
\hline Transnistria & & & & & $*$ & & & & & & & $*$ & \\
\hline South Ossetia & & & & & & & & & & & & $*$ & \\
\hline Donetsk People's Republic & & & $*$ & & & & & & & & & & $*$ \\
\hline Luhansk People's Republic & & & $*$ & & & & & & & & & & $*$ \\
\hline
\end{tabular}

Note: The population census on the territory of the future people's republics of Eastern Donbass (Donetsk and Lugansk) was carried out in 2001, when they were still part of Ukraine.

The remaining countries of the near abroad in the post-Soviet period have conducted two censuses $^{5}$, most of which occurred in two time intervals - 1999-2002 and 2009-2011, which makes it possible to trace, as a first approximation, the dynamics of their Russian population in the 1990s and 2000s. Analyzing this process in the 2010s is a much more difficult task. Current demographic data for 2017-2019 are had for only four countries (Estonia, Latvia, Kazakhstan, Kirgizia). In another three (Lithuania, Georgia, Moldova), the corresponding information on the Russian population is available for the mid-2010s. For four countries (Armenia, Azerbaijan, Belarus,

\footnotetext{
${ }^{4}$ For it, there are data from current demographic records which, however, presuppose a serious expert study.

${ }^{5}$ With the exception of Azerbaijan and Belarus, in which three censuses have already taken place, but the results of the last (2019) have not yet been published.
} 
Tajikistan), an expert assessment of the dynamics of their Russian communities is, by necessity, based on the geodemographic trends of the 1990s - 2000s.

An additional circumstance that had to be taken into account was the political fragmentation of the post-Soviet space, the emergence in the near abroad of a number of unrecognized (partially recognized) states that also conducted censuses of their population. Currently, this group has six "polities", two of which (the People's Republics of Donbass) arose only a few years ago and until the mid 2010s were regional communities of Ukraine. Finally, the inclusion of the Crimean Peninsula in the Russian Federation (March 2014), which reduced the Russian community of Ukraine by 1.5 million people, affected the overall demographic potential of the Russian near abroad and the relative proportions of its large macroregions.

It should be noted that the limited format of journal publication assumes concentration only on the central trends and aspects of the processes and phenomena analyzed.

\section{GENERAL GEODEMOGRAPHIC DYNAMICS}

Despite the significant socio-political, economic and socio-cultural differences between the countries of the near abroad, the dynamics of their Russian population reveal many similarities. First of all, the central geodemographic trend coincides: all Russian communities have declined quantitatively, and the decline has persisted throughout the post-Soviet period. It has also been ubiquitous geographically, extending to all regions and all levels of the settlement system from the capitals to the deep rural periphery.

Another common feature is that natural decrease has almost always played a subordinate role in this process. The central place, differing in time periods, macroregions and countries, belongs to migration, assimilation and various forms of change in ethnic self-identification among a part of the local Russian population - primarily among people of "mixed" origin (biethnophores), one of whose parents was Russian and the other a representative of the titular ethnic group ${ }^{6}$.

The 1990s. In general, in the 1990s the number of Russians in the near abroad decreased by almost $30 \%$ (from 25.3 to 17.8 million people). The smallest in terms of share were the quantitative losses of the Russian population of Belarus (14.9\%), as well as of Latvia and Estonia (22-26\%). The largest Russian communities in Ukraine and Kazakhstan lost a little more (27$28 \%$ ). But in absolute terms, it was these last two countries that accounted for the main quantitative decline of Russians in the near abroad (3.0 and 1.75 million people, respectively; Table 2).

\footnotetext{
${ }^{6}$ In part, such a change could represent social mimicry, the choice of a variant of national belonging that is better suited to the new conditions. But often, over time, a real transformation of the biethnophore's identity also took place.
} 
Table 2. The size of the Russian population in the near abroad, thous.

\begin{tabular}{|c|c|c|c|c|c|c|}
\hline Country $\quad$ Years & 1989 & $\begin{array}{c}1999- \\
2002 \\
\end{array}$ & $\begin{array}{c}2003- \\
2005 \\
\end{array}$ & $\begin{array}{c}2009- \\
2011 \\
\end{array}$ & $\begin{array}{c}2014- \\
2015 \\
\end{array}$ & $\begin{array}{c}2018- \\
2019 \\
\end{array}$ \\
\hline Ukraine** & 11360 & 8330 & & $6500-7500 *$ & & $\begin{array}{l}3300- \\
3800 *\end{array}$ \\
\hline Belarus & 1342 & 1142 & & 785 & & $590-650 *$ \\
\hline Uzbekistan & 1653 & $1000-1050 *$ & & $600-650 *$ & & $500-550 *$ \\
\hline Tajikistan & 388 & 68 & & 35 & & $25-30 *$ \\
\hline Turkmenia & 334 & $190-200 *$ & & $90-100 *$ & & $60-75^{*}$ \\
\hline Kazakhstan & 6228 & 4480 & & 3794 & & 3553 \\
\hline Kirgizia & 917 & 603 & & 408 & & 353 \\
\hline Georgia*** & 262 & 67.6 & & $35-38 *$ & 26,4 & $20-21 *$ \\
\hline Azerbaijan $* * * *$ & 390 & 142 & & 119 & & $75-90 *$ \\
\hline Armenia & 52 & 15 & & 12 & & $9-10 *$ \\
\hline Lithuania & 344 & 220 & & 175 & 138 & $120-130 *$ \\
\hline Latvia & 906 & 703 & & 556 & & 487 \\
\hline Estonia & 475 & 351 & & 341 & & 329 \\
\hline Moldova***** & 351 & 215-220* & 201 & $155-165 *$ & 112 & $90-100 *$ \\
\hline \multicolumn{7}{|c|}{ Unrecognized (and partially recognized) States } \\
\hline Abkhazia & 75 & $25-27 *$ & 23.4 & $22-23 *$ & 22.3 & $21-22^{*}$ \\
\hline South Ossetia & 2.1 & $0.7-0.8^{*}$ & & $0.5 *$ & 0.6 & $0,6^{*}$ \\
\hline Nagorno-Karabakh & 1.9 & $0.2 *$ & 0.17 & $0.2 *$ & 0.24 & $0.23-0.24 *$ \\
\hline $\begin{array}{l}\text { Transnistria } \\
\text { Moldavian Republic }\end{array}$ & 211 & $187-190 *$ & 185 & $165-170 *$ & 160 & $158-160 *$ \\
\hline $\begin{array}{l}\text { Donetsk and Lugansk } \\
\text { People's Republics }\end{array}$ & & & & & & $1100-1300$ \\
\hline $\begin{array}{l}\text { All the near abroad, } \\
\text { million persons }\end{array}$ & 25.29 & $\begin{array}{l}17.74- \\
17.81 *\end{array}$ & & $\begin{array}{l}13.85- \\
14.93^{*}\end{array}$ & & $\begin{array}{r}110.79 \\
11.64 *\end{array}$ \\
\hline
\end{tabular}

Source: Compiled from (All-Union census ... 1989); Population statistics of Eastern Europe and the former USSR. URL: http://pop-stat.mashke.org (date of access March 17, 2020); data from national censuses and the author's calculations.

Notes: * - Author's estimate; ** - for 2018-2019 without Crimea and the people's republics of Donbass; *** _ without Abkhazia and South Ossetia; **** - without Nagorno-Karabakh; ***** - without Transnistria.

Accelerated rates of decline were experienced by the countries of Transcaucasia, where the Russian communities decreased by a factor of 2.8-3.5 in the first post-Soviet decade. But the greatest decrease in percentage terms of the Russian population in the post-Soviet space was in Tajikistan (by a factor of 5.7), although in the rest of the Central Asian countries too the decline turned out to be quite noticeable (30-50\%).

The structure of the demographic losses of Russian communities varied significantly across macroregions and time intervals. Only in the first half of the 1990s did the entire near abroad show a certain uniformity, with the central role played by the outflow to Russia of its most "Russiancentric" part of the population, those little adapted to local life. But already by the mid-1990s the structure of attrition in individual countries was acquiring more and more particular characteristics.

In the western macroregion (Ukraine, Belarus, Moldova), a central role begins to be played by the change in self-identification of the large ethnic Russian population, which in the Soviet period self-defined as Russian and in the new socio-political and sociocultural conditions chose the identity of the titular ethnic group. In the mid-1990s, $20 \%$ of Russians in Ukraine had a Ukrainian mother and 10\% a Ukrainian father (Savoskul 2001: 89), that is, about 30\% of the Russian population of the country were ethnic "semi-Ukrainians". In general, Russian-Ukrainian 
biethnophores at this time made up about $20 \%$ of the population of Ukraine. The change in the identity of some representatives of this large group mainly determined the dynamics of the Russian population of Ukraine: its loss in the 1990s of 2 million people was associated with this factor (another 1 million were due to natural losses and migration outflow) (Mitrofanova, Suschiy 2017: 48).

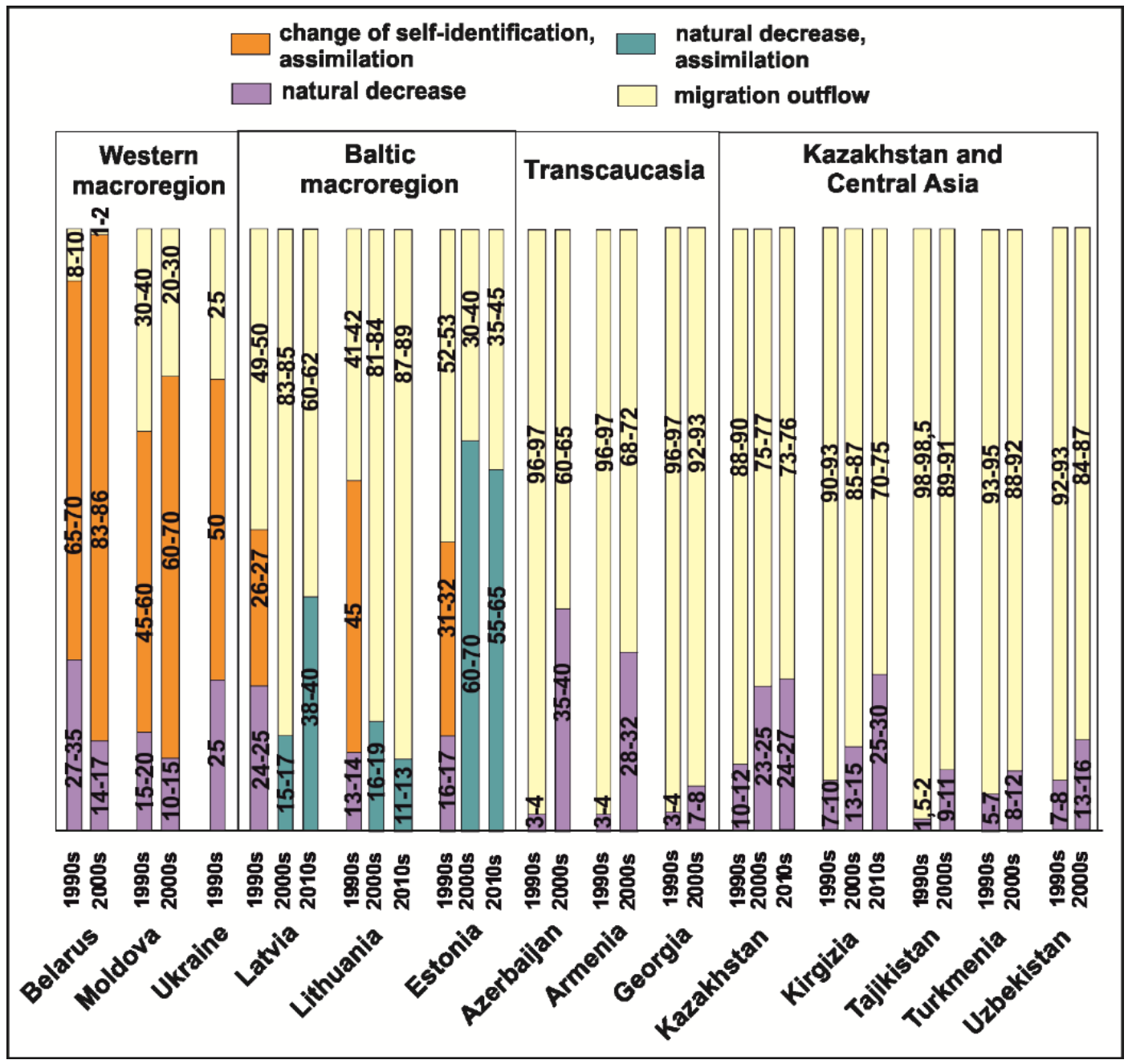

Figure 1. Components of the demographic decline of Russians in the near abroad, 1990-2010, \% ${ }^{7}$

Source: Compiled from (All-Union census ... 1989); Population statistics of Eastern Europe and the former USSR. URL: http://pop-stat.mashke.org (date of access March 17, 2020); data from national censuses and the author's calculations.

The situation was similar in the other two countries of the western macroregion. In the last Soviet decades, 70-75\% of Russians in the Belorussian Soviet Socialist Republic (BSSR) entered into interethnic marriages; for the Moldavian SSR, this figure was 57-62\% (Population of the USSR 1989: 230-231, 282-283). As a result, already in the 1990s, 7 out of 10 children of Russian women in Moldova were born to a father of a different nationality (Ostapenko, Subbotina 2011:

\footnotetext{
${ }^{7}$ For Figures 1-3, data on Moldova are given without the regions that became part of the Pridnestrovian Moldavian Republic; in Georgia - without the territory of Abkhazia and South Ossetia; and in Azerbaijan - without the territory of Nagorno-Karabakh.
} 
63-65). At the same time, the main marriage partners of Russians in these countries were representatives of the titular peoples, which significantly accelerated the assimilation of mixed offspring of interethnic families. In general, in all three countries of the western macroregion about $2 / 3$ of the decline in the Russian population recorded in the 1990s was associated with a change in identity and the assimilation of the younger generation of mixed families (Figure 1).

On a less significant scale, a change in self-identification of Russian-titular biethnophores is recorded in the second half of the 1990s in the Baltic countries (Suschiy 2018a). In the 1970s 1980s, interethnic marriages were also widespread among the Russian population of the Baltic republics of the USSR (25-29\% of Estonian Russians chose a spouse of another nationality, while 35-38\% of Latvian Russians and 47-57\% of Lithuanian Russians also did so) (Population of the USSR 1989: 276-277, 286-287, 318-319). But, in contrast to the western macroregion, the main marriage partners of Russians in the Baltics were representatives of Russian-speaking communities (primarily Ukrainians and Belarusians). The share of Russian-titular marriages remained limited, although it gradually increased. But in the new socio-political conditions, not only titular, but also other European identities (Polish, German, etc.) turned out to be more attractive, in which a part of the mixed population, who had previously identified themselves as Russian, also preferred to self-determine. Altogether, in the 1990s a change of identity could account for about 30-46\% of the quantitative loss of Russians recorded in the Baltic countries (Suschiy 2018a: 24).

About $40-50 \%$ of the decline in the Russian population of the northwestern macroregion recorded in the 1990s was associated with migration. However, outflow to Russia as a significant factor in the demographic dynamics of Russians in the Baltic states was limited only to 1992-1994 (respectively 64.6, 36.0 and 20.1 thousand people per year) (Savoskul 2001: 285). Already in the second half of the 1990s, the average annual net outflow fell to 12-13 thousand people. The same number, on the whole, was accounted for by the natural loss that had increased by this time, which in Estonia rose to $6 \%$ per year, and in Latvia was $7.5 \%$ (Buzaev 2016). In the two southern macroregions of the near abroad in the first post-Soviet decade the decline of the Russian population was associated almost exclusively with its outflow: in some countries, $88-97 \%$ of the decline was due to migration ${ }^{8}$.

The assimilation component of the demographic dynamics of Russians in the states of Transcaucasia was minimal due to the small number of Russian-titular biethnophores. In addition, this group was absolutely dominated by the offspring of interethnic families represented by a "titular" father and a Russian mother. And already in Soviet times a significant majority of such biethnophores had chosen the titular identity.

The situation was different in Central Asia, in a number of whose countries the assimilation dynamics more likely contributed to the replenishment of Russian communities in connection with the Russification of a part of the representatives of large Russian-speaking diasporas, primarily Ukrainian, Belarusian and German. This process was recorded already in the 1960s-1970s, but it accelerated noticeably in the post-Soviet period after the most nationally oriented representatives

\footnotetext{
${ }^{8}$ Net migration of Russians from the CIS and Baltic countries, 1992-2001 URL: http://allrefs.net/c4/4e7nk/p11/ (date of access 03/17/2020).
} 
of these communities returned to their historical homeland and their Russified part was preserved in the countries of the macroregion, significantly compressed in size. For this, among the mass of the Russian-speaking and "Russian-cultural" population, the most common (and quite psychologically and socio-culturally acceptable) option was the choice of a Russian spouse with the subsequent Russification of their offspring (Existing 2018b: 26-27).

Thus, in those countries of the macroregion in which Russians constituted a significant part of the population (primarily in Kazakhstan and Kirgizia, partly in Uzbekistan), Russian communities, in fact, turned into the second (along with the titular peoples) pole of ethnic consolidation, attracting representatives of the Russian-speaking diasporas ethnogenetically and socio-culturally unrelated to Central Asia.

The 2000s. The trends in the demographic dynamics of Russians in the near abroad that were formed in the 1990s have continued into the 21st century. All Russian communities are characterized by quite significant natural losses, supplemented by migration losses. But the socioeconomic stabilization of the post-Soviet space and the growth of incomes and living standards of a significant part of the population have affected the scale of the outflow of Russians, which has fallen significantly. Also working to reduce migration is the fact that the bulk of Russians determined to leave had already left the near abroad by this time, leaving mainly those who had somehow managed to adapt to post-Soviet realities, including the well-known losses of status and the obvious dominance of the titular groups in all prestigious social hierarchies. As a result, the rate of decline of the Russian population in the 2000s decreased in 9 out of 12 neighboring countries for which a fairly reliable analysis was possible 9 .

The total number of Russians in this group of countries decreased in this decade by 2.8-2.9 million people. As in the 1990s, the main loss occurred in the two largest communities: Russians in Ukraine and Kazakhstan (1.0-1.8 and 0.65 million people, respectively) ${ }^{10}$. The Russian population of Uzbekistan could have suffered significant quantitative losses (about 400-450 thousand people), decreasing by 2010 to 500-700 thousand (Arefiev 2012: 121; Khoperskaya 2012: 2). In Belarus, the number of Russians decreased by more than 350 thousand, while the Russian communities of Latvia and Kirgizia lost between 150 and 200 thousand $^{11}$.

Also transformed to some extent was the composition of the group of countries with the highest rates of Russian losses. Georgia and Tajikistan remained, while Turkmenistan and Uzbekistan appeared (Table 3). In all these countries, the Russian communities lost about 40-50\% of their number in the 2000s. The minimum rate of losses in the first decade of the 21 st century was had by the Russian populations of Estonia (2.8\%) and Kazakhstan (15.3\%).

\footnotetext{
${ }^{9}$ However, even after slowing down, these rates remained quite high, in most countries of the near abroad coming to $1.6-2.2 \%$ per year.

${ }^{10}$ Recall that the data for Ukraine is a calculated estimate, since after 2001 there were no population censuses in the country.

${ }^{11}$ Calculated according to Population statistics of Eastern Europe and the former USSR.

URL: http://pop-stat.mashke.org (date of access March 17, 2020).
} 
Table 3. Reduction of the Russian population in the countries of the near abroad, 1989-2019, \%

\begin{tabular}{lrrrr}
\hline Country & $1989-1999 / 2002$ & $1999 / 2002-2009 / 2011$ & $2009 / 2011-2018 / 2019$ \\
\hline Ukraine & 26.7 & $10-22^{*}$ & $49-50^{*}(14-20)^{* *}$ \\
Belarus & 14.9 & 31.3 & $17.2-24.8^{*}$ \\
Uzbekistan & $36.5-39.5^{*}$ & $38-40^{*}$ & $15.4-16.7^{*}$ \\
Tajikistan & 82.5 & 48.5 & $14.3-28.6^{*}$ \\
Turkmenia & $40-43^{*}$ & $50-52.5^{*}$ & $25-33^{*}$ \\
Kazakhstan & 28.1 & 15.3 & 6.4 \\
Kirgizia & 34.2 & 32.3 & 13.5 \\
Georgia & 74.2 & $44-48^{*}$ & $43-45^{*}$ \\
Azerbaijan & 63.6 & 16.2 & $24.5-37^{*}$ \\
Armenia & 71.2 & 20.0 & $17-25^{*}$ \\
Lithuania & 36.0 & 20.5 & $26-31^{*}$ \\
Latvia & 22.4 & 20.9 & 12.4 \\
Estonia & 26.1 & 2.8 & 3.5 \\
Moldova & $37.3-38.7$ & $25-28^{*}$ & $39.4-42^{*}$ \\
& Unrecognized (and partially recognized) States & \\
Abkhazia & & & $4.3-8.7$ \\
South Ossetia & $64-66.7$ & $12.0-14.8$ & 20.0 \\
Nagorno-Karabakh & $61.9-66.7$ & $28.6-37.5$ & $15-20$ \\
Transnistria & 89.5 & 0.0 & $4.2-5.9$ \\
Moldovan Republic & 11.4 & $10.5-11.8$ & $20.8-22^{*}$ \\
All the near abroad & & & $(10.5-11)^{* *}$ \\
\hline
\end{tabular}

Source: Compiled from (All-Union census ... 1989); Population statistics of Eastern Europe and the former USSR. URL: http://pop-stat.mashke.org (date of access March 17, 2020); data from national censuses and the author's calculations.

Notes: * - Author's estimate; ** - the indicator of loss is given in brackets, excluding Crimea and Sevastopol.

Altogether, the decline in the population of Russians living in the near abroad in the 2000s was 17.4-22\%. This was well below the level of the first post-Soviet decade. By the beginning of the second decade of the 21 st century, the total number of Russians in this group of countries was about 13.8-14.9 million.

The structure of the demographic losses of Russian communities, as in the 1990s, was distinguished by a noticeable diversity among various macroregions and countries.

The decline in the Russian population of the Baltic countries (primarily Lithuania and Latvia) was determined by high natural loss (7-8 \% per year) and migration, the main destination of which, however, was no longer Russia, but other EU countries (Present 2018a: 25).

In the western macroregion, the scale of the outflow of the Russian population in the $2000 \mathrm{~s}$ was insignificant. And its demographic losses were determined mainly by natural loss and assimilation of more and more numerous offspring of mixed families. By this time, already 3/4 of the marriages concluded by the Russians of Moldova were interethnic (Ostapenko, Subbotina 2011: 65). Among the Russians of Belarus, the Russian-titular biethnophores could be about 4550\%, and among the Russian population of Ukraine - 43-45\% (Mitrofanova, Suschiy 2017: 52). As a result, about $65-85 \%$ of the losses of the Russian population of the western macroregion could be attributed to assimilation. Moreover, in Belarus, the rate of demographic decline more than doubled compared to the 1990s. 
In the two southern macroregions, migration remained the main reason for the decline in Russian communities in the first decade of the 21 st century. Calculations show that about $60-70 \%$ of the loss of the Russian population of Armenia and Azerbaijan was associated with it, and more than $90 \%$ of the losses of the Russian community of Georgia. In Central Asia, the outflow could account for $75-77 \%$ of the decline in the Russian population of Kazakhstan, with corresponding figures of $84-88 \%$ for Kirgizia and Uzbekistan and about $90 \%$ for Tajikistan.

The 2010s. The analysis of geodemographic trends in the 2010s, as already noted, is seriously hampered by the fragmented nature of the available information. An expert assessment of the current Russian population in Ukraine is extremely difficult. The size of the loss associated with the transition of the Crimean Peninsula to the Russian Federation is known. But only a first rough approximation can be made of the ethno-demographic consequences of a protracted military conflict in the east of the country, of the emergence of the People's Republics of Donbass, of the multidirectional migration and of the dramatic increase in assimilation processes on both sides of the border dividing the DPR-LPR and the rest of Ukraine.

In this first approximation, it seems possible to estimate the number of Russians in modern Ukraine (excluding the People's Republics of Donbass) at 3.3-3.8 million people, which is slightly less than the results of the calculation previously made (Mitrofanova, Sushi 2017: 55). This value is already comparable to the size of the Russian population of Kazakhstan, which, according to current records, at the beginning of 2019 was 3.53 million. It should be noted that although the absolute scale of the demographic decline of Russians in Kazakhstan in the 2010s was very significant (241 thousand people for 2009-2019), in percentage terms (6.4\%) this decline was almost minimal among the countries of the near abroad. Only the Russian community in Estonia lost less $(3.5 \%)$. In two other countries (Latvia and Kirgizia), the relative losses of the Russian population in the $2010 \mathrm{~s}$ amounted to $12.4 \%$ and $13.5 \%$, respectively, and in 6 others they were in the range of 17-30\%. The maximum losses were in the Russian communities of Georgia and Moldova (between 39 and 45\%).

Considering that the natural decline of Russians in the near abroad over this ten-year period, depending on the country, ranged from 1.5\% (Kazakhstan) to 7-8\% (Lithuania, Latvia), the demographic losses of Russian communities in almost the entire post-Soviet space in the 2010s were still largely determined by other causes. For the Baltic states, as in the 2000s, this was an outflow to the more developed and successful countries of the European Union, although in Lithuania and Latvia there was also an increase in the importance of assimilation of mixed offspring of Russian-titular families, the total number of which increased noticeably at the beginning of the 21st century. Thus, out of almost 5 thousand children born in 2015 in Latvia to Russian mothers, only $60 \%$ had a Russian father. $26 \%$ of these newborns had a Latvian father (Buzaev 2016: 26).

For the countries of the western macroregion, the central factor in the demographic decline of the Russian population was also the increasing rate of its mixing with the titular peoples through interethnic marriage, with the subsequent assimilation of a significant part of their offspring (Ostapenko, Subbotina 2011: 65; Mitrofanova, Suschiy 2017: 49-50).

In Transcaucasia and Central Asia, among the factors of the decline in the number of Russians migration outflow continued to dominate, accounting for $70-90 \%$ of the decline in most 
countries of these two macroregions. In the last 5-10 years, though, in Russian communities with the maximum demographic "contraction" in the post-Soviet period due to serious gender and age disproportions, the natural reproductive factor is beginning to play an increasing role in the overall decline.

Here, one should take into account the overall curve of the natural dynamics of Russians in the post-Soviet period, which coincided for Russia and the near abroad. After an abrupt period of decline (1990s), the entire Russian population showed a gradual improvement in fertility and mortality rates, which made it possible in the first half of the 2010 s to significantly reduce natural losses throughout the post-Soviet space. But starting from the middle of this decade, Russians in all countries of this group have recorded a new drop in fertility associated with the entry into adulthood of the small generations of the 1990s. Accordingly, in 2016-2019 the scale of natural decrease also "grew".

Between 2018 and 2019 the total number of Russians in the near abroad could have been on the order of 10.7-11.6 million, i.e., 3.1-3.3 million fewer than at the end of the 2000s. But almost half of this reduction (about 1.5 million people) was associated with the transfer of Crimea to the Russian Federation. That is, demographic processes directly caused a loss of 1.6-1.8 million members of Russian communities, a reduction of 2-2.5 times the level in the 2000s.

The main reason for the slowdown in the decline of Russians in the near abroad is their serious demographic "contraction" that has already occurred. On the whole, over the post-Soviet period the number of Russians in the near abroad has decreased by a factor of 2.2-2.4 (from 25.3 to 10.7-11.6 million people). While, in $1989,17.4 \%$ of the Russian population of the USSR lived in union republics, by the end of the 2010s the near abroad of Russia accounted for only 8.5-9\% of Russians living within the former Soviet Union.

At present, 6-8\% of the number of Russians in Georgia and Tajikistan at the end of the 1980s and start of the 1990s remains there, with a corresponding number of about $14-20 \%$ in Armenia, Azerbaijan, and Turkmenistan. Only in three neighboring countries (Latvia, Estonia, Kazakhstan) have Russian communities managed to retain more than half of their "Soviet" size. Estonia is the obvious leader here (69\%) (excluding unrecognized and partially recognized states, which will be discussed below; Figure 2).

The share of Russians in the population of the near abroad has also been declining. However, the rate of this decline has been determined not only by the scale of the demographic losses of the Russian communities themselves, but also by the dynamics of the entire population of each of the post-Soviet States. The general depopulation of the Baltic states and the western macroregion, as well as of Armenia and Georgia, has reduced the percentage losses of local Russians, while the accelerated growth of the populations of Azerbaijan, Kazakhstan and Central Asia has markedly increased them. Tajikistan is the "record holder" in this regard, with the share of Russians in the 1990s - 2010s declining by a factor of about 25. But this indicator also fell severalfold in the rest of the countries of the two southern macroregions. The percentage losses of Estonia and Latvia turned out to be minimal, with Russians continuing to make up about a quarter of the population. 


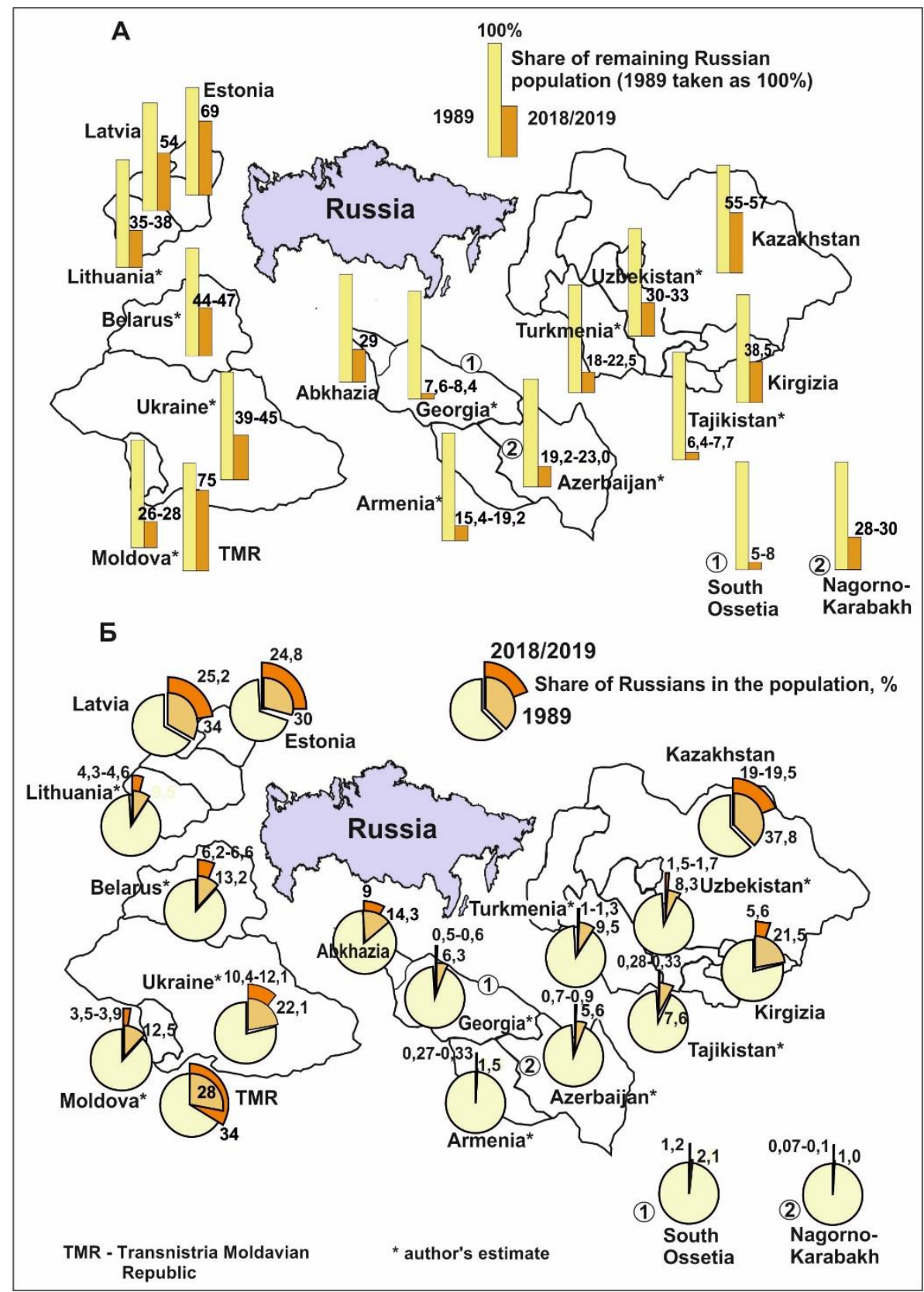

Figure 2. Dynamics of Russian communities in the near abroad, 1989-2018/2019

Source: Compiled from (All-Union census ... 1989); Population statistics of Eastern Europe and the former USSR. URL: http://pop-stat.mashke.org (date of access March 17, 2020); data from national censuses and the author's calculations.

\section{UNRECOGNIZED (PARTIALLY RECOGNIZED) STATES}

The geodemographic dynamics of the Russian population of new States arising as a result of the secession of a part of the territory of a country of the near abroad were distinguished by significant peculiarities. In the first half of the 1990s, four such States emerged in the post-Soviet space Nagorno-Karabakh, Abkhazia, South Ossetia and Transnistria. In 2014, the socio-political crisis in Ukraine led to the emergence of two self-proclaimed republics, Donetsk and Luhansk. For all these entities, with the exception of Nagorno-Karabakh, comprehensive support from Russia was 
vital. The transformation of Russia into essentially the main guarantor of the existence of these polities significantly reduced the rate and absolute scale of the decline of the Russian population.

The main quantitative losses of Russians in Transnistria, Abkhazia and South Ossetia occurred during a period of active hostilities and deep socio-economic crisis associated with war (the first half of the 1990s). Subsequently, the scale of the demographic decline of Russians decreased significantly and was mainly associated with negative natural dynamics, which ensured a significantly greater stability of Russian communities than in the countries from which these polities emerged. For example, for 2002-2014, the number of Russians in Georgia decreased by a factor of 2.6 (from 67.6 to 26.4 thousand people), and in Abkhazia in 2003-2016 - only 4.7\% .

In Moldova, between 2004 and 2014 the number of Russians decreased by 44.3\%, and in the Transnistrian Republic between 2004 and 2012 - by 13.6\%. As a result, while at the end of the 1980s the number of Russians in Transnistria was only $60 \%$ of the Russian population of the rest of the Moldavian SSR (211 and 351 thousand people, respectively), by the mid-2010s the ratio had already been reversed (160 thousand Russians in Transnistria and only 112 thousand in Moldova $)^{13}$.

The ethnopolitical and sociocultural dynamics of Ukraine and the Donbass republics in the second half of the 2010s indicate that their Russian population could change in a similar way in the long term (an accelerated reduction in the territories controlled by Kiev and the preservation of their numbers within the DPR and LPR). Should such a scenario unfold, by 2040-2050 the number of Russians in the people's republics and in the rest of Ukraine could become comparable, despite the fact that at present Ukraine's Russian population is approximately 3 times larger (3.33.8 and 1.1-1.3 million people, respectively) (Suschiy 2016: 256-263).

Thus, it was the socio-political orientation of the post-Soviet states and the level of their systemic "pro-Russianness" that were one of the central factors determining the quantitative dynamics of the local Russian population.

The total number of Russians in unrecognized (partially recognized) States of the near abroad remained insignificant until the mid-2010s (about 200 thousand people). The emergence of the People's Republics of Donbass increased this number to 1.3-1.5 million. At present, this group of countries already accounts for $12-13 \%$ of the total Russian population of the near abroad. And the ethno-demographic trends that have developed in the post-Soviet space give reason to believe that their percentage will continue to grow in the future.

\section{PerCentage DYNAMics OF RUSSIANS BY COUNTRY AND LARge MACROREGIONS}

Ukraine has continued to have the largest concentration of the Russian population in the near abroad throughout the post-Soviet period. Its share of the total number of Russians continued to

\footnotetext{
${ }^{12}$ Population statistics of Eastern Europe and the former USSR. URL: http://pop-stat.mashke.org (date of access March 17, 2020).

${ }^{13}$ Calculated according to: (All-Union Census 1989); Population statistics of Eastern Europe and the former USSR. URL: http://pop-stat.mashke.org (date of access March 17, 2020).
} 
grow during the 1990s and 2000s, gradually approaching $50 \%$. But by the end of the $2010 \mathrm{~s}$, already without Crimea, it could account for only about $41.2-43.8 \%$ of all Russians in this group of countries (4.4-5.1 million people). However, it should be borne in mind that of this number about 1.1-1.3 million were the Russian population of the People's Republics of Donbass, without whom the share of Ukraine decreases to $31-32.5 \%$, making it, as noted above, comparable to the percentage indicator of the Russian population of Kazakhstan.

Within the limits of modern Ukraine there remain several regions in which Russians are not only numerous but constitute a significant part of the local population. In the "Ukrainian" part of the Donetsk region, they account for 30-33\% of the population, in Kharkov and Zaporozhye about a quarter, in Odessa - up to 20\%, and in Dnepropetrovsk - between 16.5 and 17\% (Mitrofanova, Suschiy 2017: 52). Half of the ten largest urban centers - the centers of the Russian population of the near abroad - are still in Ukraine (in addition to Donetsk, these are Kharkov, Odessa, Kiev and Dnepropetrovsk).

The share of the Russian community of Belarus in the structure of the entire Russian population in the 1990s-2010s could have grown somewhat (from 5.3 to $5.5-5.6 \%$ ), while Moldova, taken together with Transnistria, remained unchanged (2, 2\%; Figure 3). As a result, in the post-Soviet period the share of the entire western macroregion, which still accounts for about half (49-51.7\%) of the Russian population of the near abroad, has hardly changed in the postSoviet period.

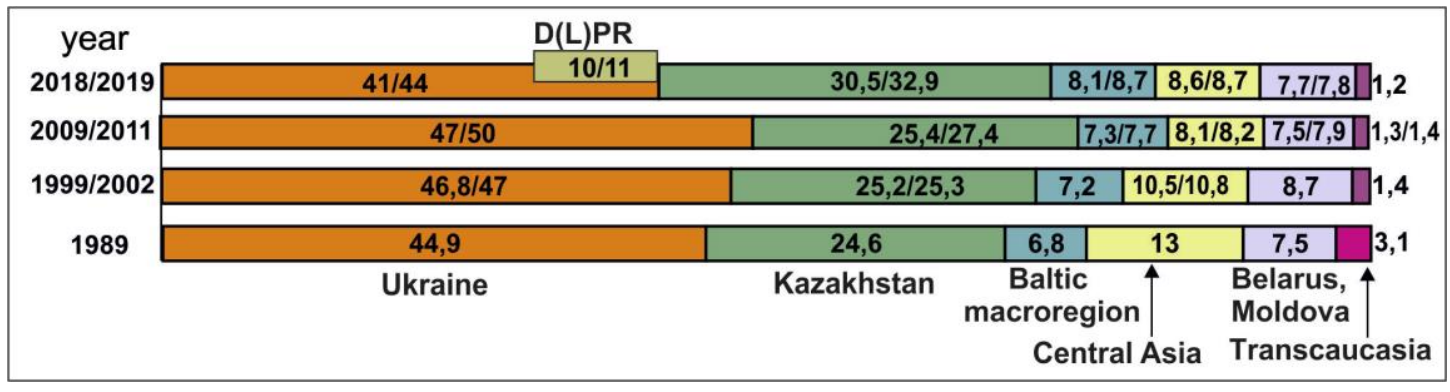

Figure 3. The share of individual countries and macroregions in the total Russian population of the near abroad (former union republics of the USSR), 1989-2018/2019, \%

Source: Compiled from (All-Union census ... 1989); Population statistics of Eastern Europe and the former USSR. URL: http://pop-stat.mashke.org (date of access March 17, 2020); data from national censuses and the author's calculations.

Note: For Moldova, data for 1999-2019 take into account the Russians of Transnistria.

Over the three post-Soviet decades, it is the Russian population of Transcaucasia that has declined the most, and the main part of this process had already been "completed" in the 1990s. By the beginning of the 21st century, 250 thousand Russians remained in the macroregion - 3.1 times fewer than in 1989 (785 thousand). But the accelerating depopulation of the majority of local Russian communities continued in the 2000s and 2010s. By now, about 120-130 thousand Russians may remain in Transcaucasia. About half of them are concentrated in Baku. Other major 
Russian territorial centers include Tbilisi (10-12 thousand) and Abkhazia (20-21 thousand) ${ }^{14}$. Thus, at present, the most significant number of Russians in the macroregion are residents of two capital centers and one partially recognized State bordering Russia.

In Central Asia, Tajikistan was the first of the post-Soviet states to almost completely lose its Russian population: in 1989-2000 its Russian community fell from 388 to 68 thousand people. About $1 / 5$ and $1 / 3$ of Russians from the level of the late 1980s remain, respectively, in Turkmenistan and Uzbekistan. The Russian community of Kirgizia has been better preserved, but it also shrank by a factor of 2.6 in the 1990s - 2010s. In the late $2010 \mathrm{~s}$, the total number of Russians in Central Asia was about 0.94-1.0 million people, about half of whom were in two capitals - Tashkent (300-350 thousand) and Bishkek (about 170 thousand) (Fedorko, Kurbanov 2018: 44).

The number of Russians in Kazakhstan has decreased in the post-Soviet period by more than 2.5 million people. But in percentage terms, this decline was only 43-44\%, which was one of the lowest rates in the entire post-Soviet space. This circumstance allowed the Russian community of the country to significantly increase its share in the structure of the Russian population of the entire near abroad (in the 1990s - 2010s it grew from 24.6 to 30.5-32.9\%). The second capital of Kazakhstan, Alma-Ata, is the largest center of the Russian population in the near abroad (468 thousand in 2019). Karaganda (203 thousand) and Ust-Kamenogorsk (183 thousand) are also in the top ten cities of Kazakhstan.

Compared to other macro-regions of the near abroad, the Russian population of the Baltic has also survived quite well, despite the fact that its dynamics vary significantly in individual countries. The rate of decline of Russians in Lithuania was comparable to that of the Central Asian states (by the end of the 2010s, 35-38\% of the Russian population remained in Lithuania from the 1989 level), and the Russian community in Estonia demonstrated the greatest stability in the entire group of post-Soviet countries ${ }^{15}$. Currently, about $940-950$ thousand Russians remain in the Baltic countries, $82-83 \%$ fewer than at the end of the Soviet period.

Significant differences in the rate of decline have affected the overall ratio of the Russian population in various macroregions. While the significant scale of the Russian communities in Ukraine and Kazakhstan allows these countries to remain the main centers of Russians within the near abroad of Russia, the ratio of communities in other macroregions has changed. The Russian population of the Baltic states, which in the late 1980s lagged behind that of Central Asia by almost 2 times (6.8 and 13\%, respectively), by the end of the 2010s had practically caught up with it (8.18.7 and 8.6-8.7\%), at the same time overtaking the size of the Russian communities in Belarus and Moldova. The share of Russians in Transcaucasia, who currently account for only $1.2 \%$ of the

\footnotetext{
${ }^{14}$ All other centers/territories had significantly lower numbers than those listed. Among the urban communities, one can single out the Russians of Yerevan (4-4.5 thousand), Sumgait (1.5-1.7 thousand) and Rustavi (1.0-1.2 thousand). Population statistics of Eastern Europe and the former USSR. URL: http://pop-stat.mashke.org (date of access March 17, 2020).

${ }^{15}$ Except for the unrecognized republic of Transnistria. 
Russian population of the near abroad, has significantly decreased. At the end of the 1980 s and start of the 1990 s this figure was about $3 \%{ }^{16}$.

\section{Age AND SEX STRUCTURE OF THE RUSSIAN POPULATION}

Along with a decline in numbers, Russians of the near abroad in the post-Soviet period have undergone an appreciable transformation of their gender balance and age structure. The active migration outflow not only reduced Russian communities, but, above all, "leached out" young people and people of middle working age. As a result, the "oldest" communities, as a rule, have turned out to be those suffering the greatest migration losses in the post-Soviet period. But the shift in the age structure towards the older generations has had a negative effect on natural reproduction indices. Moreover, a central role in growing natural decrease was played by low fertility (mortality, as a rule, corresponded to the Russian indicator).

The median age of Russians in most countries of the near abroad was 40-42 years by the beginning of the 21 st century, and by now it is likely to have grown by another 2-3 years. In a number of post-Soviet States (including Latvia, Lithuania and Moldova) in the mid and late 2010s it was in the range of 46-49 years. Persistence of this trend could, in the medium term, lead to an increase in the median age of Russians in these countries to 50-55 years, as a result of which the rates of natural and general demographic decline of Russians will begin to noticeably accelerate. However, it should be borne in mind that an increase in the median age of Russians has also taken place in Russia itself, where it is now also close to 40 years, slightly differing from this indicator for the Russian populations of Kazakhstan, Kirgizia, Ukraine and Belarus.

The gender structure of Russian communities in the near abroad has also been upset in the post-Soviet period. Its perceptible imbalance is associated with the growing preponderance of women, largely due to the more active outflow of the male population. It should also be taken into account that in almost all countries of the post-Soviet space Russian women were much more often than men married to representatives of the titular peoples, which also increased the gender disproportion in the migration outflow of Russians.

In the Russian community of Azerbaijan, already in 1999 there were 59 men per 100 women ${ }^{17}$. The situation was similar in other countries of the Caucasus. In the first two decades of the 21 st century, this gender imbalance increased even more. In other macro-regions of the near abroad, this imbalance is not so significant. Nevertheless, in 2009-2015, in the Russian communities of Kirgizia and Moldova there were 77-79 men per 100 women, in Kazakhstan and Estonia - 81-82 .

The growing feminization of a significant number of Russian communities in the near abroad has had a negative impact on their natural dynamics. The shortage of men has resulted in

\footnotetext{
${ }^{16}$ It should be noted that in 1959 Transcaucasia accounted for $5.9 \%$ of the Russian population of the union republics of the USSR. Thus, the process of the outflow of Russians from this macroregion began long before the collapse of the Soviet Union.

${ }^{17}$ Yunusov A.S. (2003). Ethnic and migration processes in post-Soviet Azerbaijan. URL: http://chairs.stavsu.ru/geo/Conference/c1-67.htm

18 According to the national censuses of these countries.
} 
an increase in interethnic marriage of Russian women (including with representatives of the titular nations) and an intensification of the assimilation process (Buzaev 2016; Ostapenko, Subbotina 2011: 65).

\section{SETTLEMENT FORM}

As already noted, the decline of Russians within the near abroad has been widespread. But there have been certain shifts in the ratio of various forms of settlement. During the Soviet period, the Russian population of most of the union republics was distinguished by an increased level of urbanization. In 1989, in five of them, the share of city dwellers among local Russians was 9297\%, in seven - 85-90\%. Only in Kazakhstan and Kirgizia was this level significantly lower (77 and 69.9\%, respectively) (All-Union census ... 1989).

In the post-Soviet period, out of 11 countries for which there was relevant information, the proportion of urban dwellers among the Russian population increased only in Azerbaijan, did not change in Tajikistan and Ukraine, and decreased in 8 countries - in three quite significantly (in Armenia, Latvia, Moldova; Figure 4). In general, the rural Russian population of the near abroad has shown a higher degree of rootedness than the urban population.

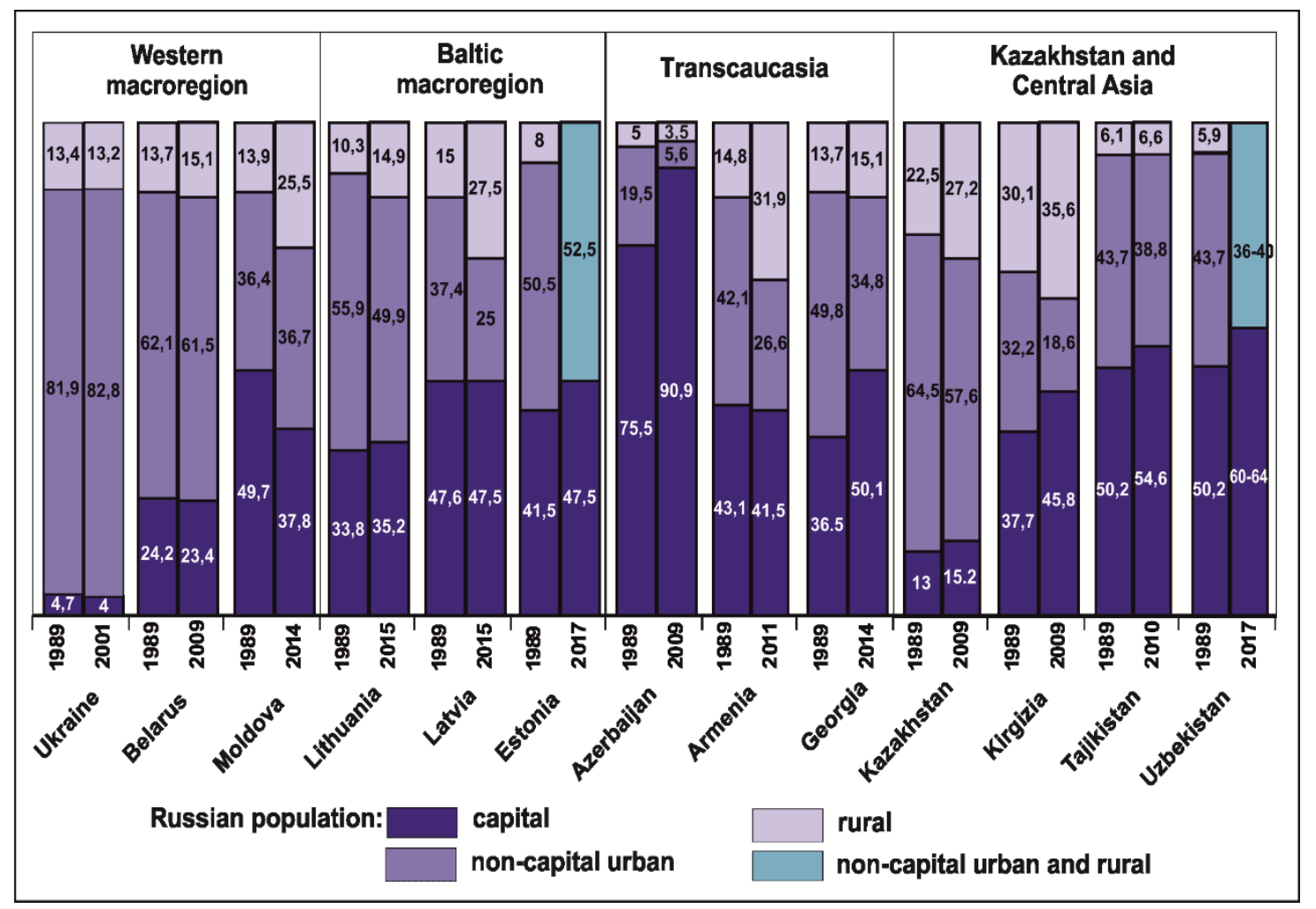

Figure 4. The share of different levels of the settlement system in the distribution of the Russian population of the near abroad (union republics of the USSR), \%

Source: Compiled from (All-Union census ... 1989); Population statistics of Eastern Europe and the former USSR. URL: http://pop-stat.mashke.org (date of access March 17, 2020); data from national censuses and the author's calculations. 
But among the Russian city dwellers, the ratio between the capital and the rest of the population has noticeably changed. In six of the thirteen countries of the near abroad, the share of Russians concentrated in the capitals has increased (especially noticeably in Georgia, Azerbaijan, and Uzbekistan), while in four it has hardly changed. At the same time, the proportion of "noncapital" Russian city dwellers has decreased in eight out of eleven countries. In other words, regional urban networks have been losing their Russian population at an accelerated rate, since, in addition to the outflow to Russia and the far abroad, some of their Russian residents have moved to the capital centers. Thus, there is a certain "polarization" of the Russian settlement system, concentrated in the capitals and in the countryside. But it should not be forgotten that these shifts occurred at different rates of decline, and in any case were associated with the growing fragmentation of the settlement system and the gradual territorial enclavation of the Russian population.

In Central Asia, Russians have left the countryside almost entirely. Even in Kirgizia, which has preserved more than 120 thousand people of the rural Russian population, it is almost entirely concentrated in the vicinity of the capital Bishkek (Chui oblast) and partly in the Issyk-Kul oblast. In Uzbekistan, it is largely limited to the rural environs of Tashkent and a number of regional centers.

The smallest number of rural Russians remains in the Transcaucasus, while their share in the structure of Russian communities has changed in different directions (decreasing in Georgia, not changing in Azerbaijan, increasing in Armenia). But in all three States the number of settlements without Russian residents has increased many times over. And the epicenters of the Russian ethnic presence in the rural areas of the Transcaucasus remain rare Old Believer villages (the province of Lori in Armenia, Ismaily in Azerbaijan).

The geography of rural Russians has also significantly decreased in two other macroregions of the near abroad, although here their settlement system remains, as a rule, wider (with the exception of Moldova and Lithuania). However, the largest Russian rural population is in Kazakhstan, which accounts for up to half of its population in the entire near abroad (940-950 thousand out of 1.94-1.95 million people). About 500-570 thousand rural Russians live in Ukraine (including 100-120 thousand in the republics of Donbass), more than 130 thousand in Latvia and 90-95 thousand in Belarus.

\section{CONCLUSIONS}

In the 1990-2010s the Russian population of the near abroad decreased from 25.3 to 10.7-11.7 million people. This process was most intensive in the first post-Soviet decade. The decline was widespread, covering all levels of the settlement system (from the capitals to the rural periphery). The Russians almost completely left the States of post-Soviet Transcaucasia, as well as Tajikistan. Their demographic losses also turned out to be significant in other countries of the post-Soviet space. Only in three States (Estonia, Latvia and Kazakhstan) is the number of Russians now more than $50 \%$ of the 1989 figure.

The age and sex structure of Russian communities has been significantly deformed. Almost all of them have a noticeable preponderance of women, which in some countries is already almost 
double (55-60 men per 100 women). The median age of the Russian population in all countries of the near abroad exceeds 40 years, and in almost half it is in the range of 45-50 years, which is becoming one of the reasons for the increased level of natural decrease ( $8-10 \%$ per year or more).

The ratio of various factors of quantitative decline have varied across the periods and macroregions of the post-Soviet space. For the early to mid-1990s, the greatest losses of almost all Russian communities are associated with migration outflow to Russia. Later, the general trend is replaced by many trends typical for different countries. In the western macroregion (Ukraine, Belarus, Moldova), the change of identity by part of the Russian-titular biethnophores, assimilation processes associated with the growth of interethnic marriage of the Russian population and the choice of the titular nationality by the mixed offspring of such families begin to play a central role. The Baltic region (for Lithuania and Latvia) is also characterized by a certain intensification of assimilation, but the main reason for the quantitative reduction since the beginning of the 21st century is the outflow of Russians to the far abroad. In Transcaucasia and Central Asia, throughout the post-Soviet period migration to Russia has played a leading role in the demographic decline of Russians.

The level of urbanization of the Russian population in most countries of the near abroad in the 1990s-2010s decreased due to the rapid loss of non-capital city dwellers. The metropolitan and the rural Russian populations were the best preserved, which contributed to a certain spatial polarization of the settlement system, with a concentration of Russians on its upper and lower floors. However, a significant number of Russians who had remained in rural areas were also drawn towards capitals and other large centers.

The proportion of Russians in individual countries and macroregions has changed. Currently, the numbers of Russians in Ukraine (excluding the People's Republics of Donbass) and Kazakhstan are already comparable. In the medium term (2030-2035), it is Kazakhstan that is likely to become the largest concentration of the Russian population in the near abroad, and the Baltic countries will overtake Central Asia in terms of this indicator.

Russian communities of unrecognized (partially recognized) States that emerged in the post-Soviet space are distinguished by a higher demographic stability in the 2000s and 2010s. After they acquired de facto independence, the rate of decline in the local Russian population decreased significantly and was linked above all to natural decrease. At present, this group of "polities" already accounts for about $12-13 \%$ of Russians in the entire near abroad. And this number is likely to continue to grow in the future.

In general, the share of post-Soviet Russians concentrated in Russia itself is steadily growing, while the share of Russian communities in the entire near abroad is decreasing. In the 1990s and 2010s it was halved (from 17.4 to 8.5-9\%), which is the result of a whole complex of processes: the natural decrease of the Russian population, its migration to Russia and the far abroad and assimilation into the titular peoples. The rates and absolute scale of the absolute and relative reduction of Russian communities are gradually decreasing. But the trend itself remains stable throughout the post-Soviet period. 


\section{REFERENCES}

Aleinikov M.V., Borovikov I.V. (2013). Russian population of Kazakhstan: socio-demographic transformations (the 90s of the XX century). Mir Evrazii [Eurasia World], 21 (2), 2-8. (In Russ.).

Arefiev A.L. (2012). Russkiy yazyk na rubezhe XX-XXI vekov [Russian language at the turn of the XX-XXI centuries]. Moscow: TSentr sotsial'nogo prognozirovaniya. (In Russ.).

Buzaev V. (2016). Pravovoye i fakticheskoye polozheniye russkogovoryashchego men 'shinstva v Latvii [The legal and actual situation of the Russian-speaking minority in Latvia]. Riga. (In Russ.).

Fedorko V.N., Kurbanov Sh.B. (2018). Etnogeograficheskoye rayonirovaniye Uzbekistana [Ethno-geographical zoning of Uzbekistan]. Izvestiya geograficheskogo obshchestva Uzbekistana [News of the Geographical Society of Uzbekistan], 54 (Tashkent), 42-53. (In Russ.)

Kabuzan V.M. (1996). Russkiye v mire [Russians in the world]. St. Petersburg: Blits. (In Russ.).

Khallik K.S. (2011). Russkiye v Estonii [Russians in Estonia]. In Russkiye: etnosotsiologicheskiye issledovaniya [Russians: ethnosociological research] (pp. 90-119). Moscow: Nauka. (In Russ.)

Khoperskaya L.L. (2012). Rossiyskiye sootechestvenniki v TSentral'noy Azii demograficheskiy resurs, otrezannyy lomot' ili khraniteli russkogo mira? [Are Russian compatriots in Central Asia a demographic resource, a slice cut off or keepers of the Russian world?]. Etnopanorama, 3-4, 5-12. (In Russ.)

Manakov A.G. (2020). Territorial'nyye razlichiya v dole russkikh v postsovetskikh stranakh Vostochnoy Evropy i Baltii [Territorial differences in the share of Russians in the post-Soviet countries of Eastern Europe and the Baltic]. Izvestiya Akademii Nauk. Seriya geograficheskaya, 2, 179-190. (In Russ.). DOI: 10.31857/S2587556620020090

Manakov A.G., Chuchenkova O.A. (2016). Izmeneniye chislennosti i etnicheskoy struktury naseleniya Pskovo-Baltiyskogo regiona s 1897 po $2015 \mathrm{gg}$. [Change in the number and ethnic structure of the population of the Pskov-Baltic region from 1897 to 2015]. Vestnik Pskovskogo gosudarstvennogo universiteta, Seriya «Estestvennyye i fiziko-matematicheskiye nauki», 8, 77-88. (In Russ.).

Martsinkyavichus A. (2013). Russkiye v nezavisimoy i sovetskoy Litve: demografiya, sotsial'noye polozheniye, identichnost' [Russians in independent and Soviet Lithuania: demography, social status, identity]. In Etnicheskaya politika $v$ stranakh Baltii [Ethnic policy in the Baltic countries] (pp. 197-218). Moscow: Nauka. (In Russ.).

Mitrofanova I.V., Sushchiy S.Ya. (2017). Russkiye na Ukraine: geodemograficheskiye itogi postsovetskogo perioda i srednesrochnyye perspektivy. Sotsiologicheskiye issledovaniya, 8 , 46-59. (In Russ.).

Mozaki N.Z. (2018). Etnicheskaya kartina Gruzii po rezul'tatam perepisi 2014 g. [Ethnic picture of Georgia according to the results of the 2014 census]. Etnograficheskoye obozreniye, 1, 104-120. (In Russ.).

Naseleniye SSSR [The population of the USSR] (1989). Moscow: Finansy i statistika. (In Russ.).

Nikiforov I.V., Poleschuk V.V. (2013). Demografiya russkogo naseleniya Estonii v XX veke

[Demography of the Russian population of Estonia in the twentieth century]. In Etnicheskaya 
politika v stranakh Baltii [Ethnic policy in the Baltic countries] (pp. 155-176). Moscow: Nauka. (In Russ.)

Ostapenko L.V., Subbotina I.A. (2011). Russkiye v Moldavii: sotsial'no-demograficheskiye transformatsii. Sotsiologicheskiye issledovaniya, (5), 61-71. (In Russ.).

Perepis' naseleniya Moldovy 2014 [Census of Moldova 2014] (2014). Retrieved from https://recensamint.statistica.md/en/dissemination/person (data downloaded on 12.04.2020).

Romantsov V.O. (2008). Naselennya Ukraïni i yogo ridna mova za chasiv radyans'koï vladi ta nezalezhnosti (XX - pochatok XXI stolittya) [The population of Ukraine and its native language during the days of Soviet power and independence: $\mathrm{XX}$ - the beginning of the XXI century]. Kiev: Izdatel'stvo im. O. Teligy. (In Russ.).

Rybakovsky L.L. (1996). Rossiya i novoye zarubezh'ye: migratsionnyy obmen i ego vliyaniye na demograficheskuyu dinamiku [Russia and the New Abroad: Migration Exchange and its Impact on Demographic Dynamics]. Moscow: ISPI RAN. (In Russ.).

Savoskul S.S. (2001). Russkiye novogo zarubezh'ya: Vybor sud'by [Russian new abroad: the choice of fate]. Moscow: Nauka. (In Russ.).

Statistika Estonii. Baza dannykh [Statistics of Estonia. Database] (2020). Retrieved from http: //andmebaas.stat.ee/ (data downloaded on 04.04.2020).

Sushchiy S.YA. (2016). Etnodemograficheskiye aspekty russko-ukrainskogo vzaimodeystviya (Ukraina i YUg Rossii) [Ethnodemographic aspects of Russian-Ukrainian interaction (Ukraine and the South of Russia)]. LAP LAMBERT Academic Publishing.

Sushchiy S.YA. (2018a). Russkiye v Pribaltike - geodemograficheskiye trendy postsovetskogo perioda i perspektivy pervoy poloviny XXI veka [Russians in the Baltics - geodemographic trends of the post-Soviet period and prospects for rst half of the XXIst century]. Narodonaseleniye, 21(3), 21-36. DOI: 10.26653/1561-7785-2018-21-3-02. (In Russ.)

Sushchiy S.YA. (2018b). Russkiye Kazakhstana - geodemograficheskaya dinamika postsovetskogo perioda i perspektivy pervoy poloviny XXI veka. Sotsiologicheskiye issledovaniya, 8, 22-37. (In Russ.) DOI: 10.31857/S013216250000759-7

Tishkov V.A. (1993). Russkiye v Sredney Azii i Kazakhstane [Russians in Central Asia and Kazakhstan]. In Issledovaniya po prikladnoy i neotlozhnoy etnologii [Studies in applied and urgent ethnology] (Doc. no. 51). Moscow: IEARAN. (In Russ.).

Tsutsiev A.A. (2006). Atlas etnopoliticheskoy istorii Kavkaza (1774-2004). [Atlas of the ethnopolitical history of the Caucasus (1774-2004)]. Moscow: Evropa. (In Russ.).

Volkov V.V. (2013). Demografiya russkogo naseleniya Latvii v KHKH - XXI vv. [Demography of the Russian population of Latvia in the XX - XXI centuries]. In Etnicheskaya politika $v$ stranakh Baltii [Ethnic policy in the Baltic countries] (pp. 177-196). Moscow: Nauka. (In Russ.).

Vsesoyuznaya perepis' naseleniya 1989 goda [All-Union Population Census 1989] (1989). Demoscope Weekly. URL: http://www.demoscope.ru/weekly/ssp/resp_nac_89.php (In Russ.).

Zhukov S.V., Reznikova O.V. (2001). TSentral'naya Aziya v sotsial'no-ekonomicheskikh strukturakh sovremennogo mira [Central Asia in the socio-economic structures of the modern world]. Moscow: Moskovskiy obshchestvennyy nauchnyy fond. (In Russ.). 